OPEN ACCESS

Edited by:

Tomonori Nochi,

Tohoku University, Japan

Reviewed by:

Zhenquan Jia,

University of North Carolina at Greensboro, United States

Wei Chen,

Jiangnan University, China

*Correspondence:

V. Sukumaran

drvsukumar@gmail.com

Se Chang Park

parksec@snu.ac.k

tPresent address:

V. Sukumaran,

Department of Zoology, Kundavai

Nachiyar Government Arts College for Women (Autonomous), Thanjavur,

Tamil Nadu, India

*These authors have contributed equally to this work.

Specialty section:

This article was submitted to

Comparative Immunology,

a section of the journal

Frontiers in Immunology

Received: 29 December 2017 Accepted: 24 July 2018

Published: 07 August 2018

Citation:

Giri SS, Yun S, Jun JW, Kim HJ, Kim SG, Kang JW, Kim SW, Han SJ,

Sukumaran V and Park SC (2018)

Therapeutic Effect of Intestinal

Autochthonous Lactobacillus reuteri P16 Against Waterborne Lead Toxicity in Cyprinus carpio.

Front. Immunol. 9:1824. doi: 10.3389/fimmu.2018.01824

\section{Therapeutic Effect of Intestinal Autochthonous Lactobacillus reuteri P16 Against Waterborne Lead Toxicity in Cyprinus carpio}

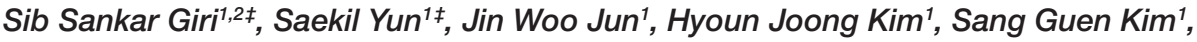 \\ Jeong Woo Kang', Sang Wha Kim¹, Se Jin Han', V. Sukumaran ${ }^{2 *}$ and Se Chang Park ${ }^{1 *}$ \\ ${ }^{1}$ Laboratory of Aquatic Biomedicine, College of Veterinary Medicine, Research Institute for Veterinary Science, Seoul \\ National University, Seoul, South Korea, ${ }^{2}$ Department of Biotechnology, Periyar Maniammai University, Thanjavur, India
}

Harmful effects of heavy metals are myriad. Lead $(\mathrm{Pb})$ from soil and atmosphere contaminates water bodies and affects the aquatic animals. Our previous study confirmed the in vitro probiotic potential of Lactobacillus reuteri against $\mathrm{Pb}$ toxicity, but further investigation is necessary for gaining insights into the related protection mode. Therefore, in this study, we investigated the protective effects of the potential probiotic L. reuteri $\mathrm{P} 16$ against waterborne $\mathrm{Pb}$ exposure-induced toxicity in the freshwater fish Cyprinus carpio. Fish (average weight: $23.16 \pm 0.73 \mathrm{~g}$ ) were allocated to four groups (control, $\mathrm{Pb}$ only, $\mathrm{Pb}+L$. reuteri $\mathrm{P} 16$, and $L$. reuteri $\mathrm{P} 16$ only) and $\mathrm{Pb}$ groups were exposed to waterborne $\mathrm{Pb}\left(1 \mathrm{mg} \mathrm{L}^{-1}\right)$ for 6 weeks. L. reuteri P16 $\left(10^{8} \mathrm{CFU} \mathrm{g}{ }^{-1}\right)$ supplemented diet was provided twice daily. Growth performances, hemato-biochemical parameters, innate immune responses, intestinal microbiota, and $\mathrm{Pb}$ accumulation in tissues were measured at the end of the trial. When the fish were exposed to $\mathrm{Pb}$, dietary supplementation of $L$. reuteri $\mathrm{P} 16$ effectively decreased mortality and accumulation of $\mathrm{Pb}$ in tissues, and improved the growth performance. Co-treatment with $\mathrm{Pb}$ and L. reuteri P16 alleviated $\mathrm{Pb}$ exposure-induced oxidative stress, reversed alterations in hemato-biochemical parameters, improved innate immune parameters, and restored intestinal enzymatic activities. Moreover, L. reuteri P16 supplementation reversed the changes in intestinal microbiota in $\mathrm{Pb}$-exposed fish. Furthermore, $\mathrm{Pb}$ exposure decreased the expressions of pro-inflammatory cytokines (TNF- $\alpha, I L-1 \beta)$. However, the expression of heat shock proteins (HSP70 and HSP90) increased, which might have increased the cellular stress. Interestingly, the $\mathrm{Pb}$-induced alterations of gene expressions were reversed by $\mathrm{L}$. reuteri P16 supplementation. Thus, dietary administration of the potential probiotic $L$. reuteri P16 had several beneficial effects on growth performance and immune responses, decreased $\mathrm{Pb}$ accumulation in tissues, and reversed alterations in hematological responses of $C$. carpio. Furthermore, it offered direct protection against $\mathrm{Pb}$-induced oxidative stress. Therefore, $L$. reuteri P16 may be a novel dietary supplement for enhancing growth performance and preventing $\mathrm{Pb}$-exposure-induced toxicity in fish in aquaculture and aquatic products.

Keywords: probiotics, lactic acid bacteria, $\mathrm{Pb}$, common carp, oxidative stress, immune parameters, gene expression 


\section{INTRODUCTION}

In recent years, contamination of aquatic environments by heavy metals is increasing rapidly. These heavy metals have caused lot of problems due to their toxicity, and it poses threat to both aquaculture and food safety (1). The natural aquatic systems are being extensively contaminated with heavy metals released from industrial and other anthropogenic activities. Among the various heavy metals, lead $(\mathrm{Pb})$ is one of the most toxic and occupies the second place in Priority List of Hazardous Substances (2). Due to higher levels in the food web, fish can accumulate many metals, and the accumulation patterns in fish rely on uptake and elimination rates (3). $\mathrm{Pb}$ accumulation in fish tissues depends on the type of metal, exposure duration, and concentration, salinity, temperature, water quality, fish species, and metabolic activity of fish (4). $\mathrm{Pb}$ is mutagenic and teratogenic in humans and animals (5). Prolonged $\mathrm{Pb}$ exposure can produce adverse effects on pituitary function, gonadosomatic index, and oocyte growth, chromosomal aberrations, and causes neurological disorders, DNA damage, and scoliosis in freshwater fish (6-8). Furthermore, $\mathrm{Pb}$ showed deleterious effects on gut-associated lymphoid tissues of Channa punctatus (8). In addition to economic loss to aquaculture, heavy metal contamination in aquaculture poses great risks to human health because it can accumulate and enter the food chain (9). Therefore, eco-friendly and affordable strategies of controlling heavy metal $(\mathrm{Pb})$ contamination in aquaculture is increasing in importance.

Until date, no treatment method for chronic $\mathrm{Pb}$ poisoning has been developed. Although chelation therapy has been used to promote heavy metal excretion, chelators for $\mathrm{Pb}$ toxicity have been reported to be deficient in terms of safety and efficacy (10). Gut microbiota of fish play important roles in metabolism, immunity, and pathogen resistance (11). Allochthonous (transient) and autochthonous (adherent) microbes normally reside in gastrointestinal (GI) tract of fish, and the latter type has been well investigated for their numerous beneficial effects on the host (11). Colonization of the GI tract of fish larvae completes within few hours after hatching. The colonization by normal or protective microbes prevents colonization by potential invaders and maintains the overall health of fish (12). Lactic acid bacteria (LAB) are classified as "generally regarded as safe" and have been widely used in aquaculture (13). LAB with potential heavy metal adsorption capacity have been isolated and identified earlier (14-16). They remove heavy metals in vivo and in vitro $(14,17,18)$. Recently, Yu et al. (13) demonstrated that dietary Lactobacillus plantarum could alleviates the waterborne aluminum toxicity in tilapia. In another study, Zhai et al. (14) demonstrated that dietary probiotic L. plantarum CCFM8610 has potential to prevent cadmium-exposure induced problems in tilapia aquaculture. Therefore, LAB could be exploited further for their possible role in alleviating heavy metal toxicity in aquaculture.

Immunostimulants and other biological factors, such as probiotics, can trigger the defense system, even under stressful conditions, thereby reducing the deleterious effects caused by various biological, chemical, and physiological stresses (19).
Until date, numerous studies have demonstrated that probiotics can stimulate immunity in teleosts both under in vivo and in vitro conditions. Available literature indicates that several probiotics either individually or in combination can enhance both systemic and local immunity in fish $(20,21)$. Probiotic activities of LAB and other bacteria isolated from the GI tract of fish have been demonstrated in several studies (22-25). However, protective effect of those autochthonous probiotic bacteria against heavy metal-induced toxicity in fish has not been reported yet. Various microorganisms have been studied and strategically used for bioremediation of water polluted with heavy metals $(26,27)$. Recently, it has been found that LAB, such as L. plantarum, Lactobacillus rhamnosus, Lactobacillus reuteri, and Bifidobacterium lactis can bind and remove heavy metals in vitro from water and environment $(15,27)$. Yi et al. (17) demonstrated that Leuconostoc mesenteroides isolated from fermented kimchi has strong lead resistance and removal capacity. It has been reported that dietary supplementation

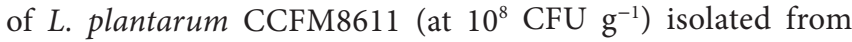
environmental samples alleviated $\mathrm{Pb}$-induced oxidative stress, reversed digestive enzyme activities and innate immune status, and ameliorated the growth performance in $\mathrm{Pb}$-induced fish (18). Hematological parameters are reliable indicators of physiological status of aquatic animals under stress due to metal exposure.

Recently, we have isolated $\mathrm{Pb}$-resistant $\mathrm{LAB}$ from the gut content of carp Cyprinus carpio (28). Among those isolates, L. reuteri $\mathrm{P} 16$ was found to exhibit strong $\mathrm{Pb}$-binding and tolerance abilities. L. reuteri P16 exhibited various probiotic properties, such as a high level of tolerance to both acid $(\mathrm{pH} 2.0$ and $3.0)$ and bile (0.3\% Oxgall) exposure, good adhesion to intestinal mucosa, strong inhibition of fish-pathogen growth in vitro, and susceptibility to several clinically effective antibiotics (28). Furthermore, "intact cells" and cell-free supernatants of P16 had stronger antioxidant abilities. Those results indicated that it is important to investigate efficacy of $L$. reuteri $\mathrm{P} 16$ in providing protection against toxicity caused by $\mathrm{Pb}$-exposure in aquaculture. C. carpio is an important aquaculture species worldwide. It is the third most widely cultivated and commercially important freshwater fish species in the world. In addition, it is recognized as a good biological model because it is easy to handle, culture, and maintain in the laboratory. Therefore, this study was aimed to investigate the effect of dietary supplementation of intestinal autochthonous $L$. reuteri P16 on the growth performance, hematological, and blood biochemical parameters, and intestinal enzymatic activities of the carp C. carpio exposed to waterborne $\mathrm{Pb}$. In addition, effects of P16 on cytokine gene expression, and $\mathrm{Pb}$ accumulation in tissues of carp were investigated.

\section{MATERIALS AND METHODS}

\section{Potential Probiotic Strain}

Lactobacillus reuteri P16 isolated from the gut content of C. carpio, exhibited in vitro probiotic properties, and excellent $\mathrm{Pb}$-binding and $\mathrm{Pb}$-tolerance capacities (28). This strain was cultured in de Man, Rosaga, and Sharpe (MRS) broth for $24 \mathrm{~h}$ at $37^{\circ} \mathrm{C}$. 


\section{Preparation of Diet for Fish}

The basal diet containing $28.8 \%$ protein, $7.16 \%$ lipid, and $12.36 \%$ ash was prepared as described in a previous study (29). The culture broth was centrifuged at $8,000 \times g$ for $15 \mathrm{~min}$ at $4^{\circ} \mathrm{C}$ to precipitate the cells. The initial bacterial concentration $\left(1.32 \times 10^{9}\right.$ cells $\mathrm{mL}^{-1}$ ) was diluted to the desired concentration using the phosphate buffer saline ( $\mathrm{pH}$ 7.4). P16 was added to the basal diet at a final concentration of $1 \times 10^{8} \mathrm{CFU} \mathrm{g}^{-1}$ (approximately). Based on a preliminary study, P16 concentration was chosen as $1 \times 10^{8} \mathrm{CFU} \mathrm{g}^{-1}$ (unpublished data). The number of viable bacterial cells in the diet was determined via plate counting on MRS agar plates. The ingredients were blended thoroughly into a mixture that and then pelleted, air-dried, ground, and sieved into appropriate pellet sizes. The experimental feed was prepared weekly and stored at $4^{\circ} \mathrm{C}$.

\section{Experimental Design}

Cyprinus carpio (average body length: $11.2 \pm 0.8 \mathrm{~cm}$; average weight: $23.16 \pm 0.73 \mathrm{~g}$; approximate age: 105 days) obtained from a local fish farm were acclimatized to laboratory conditions in $500 \mathrm{~L}$ quarantine tanks for 2 weeks at $24 \pm 2^{\circ} \mathrm{C}$ and fed a basal diet (29). Approximately $20 \%$ of the water in all the tanks was replaced daily, and $100 \%$ of the water was replaced weekly. Basic physicochemical parameters of the water were monitored weekly; oxygen and ammonia concentrations were 6.1-7.3 and $0.03-0.06 \mathrm{mg} \mathrm{L}^{-1}$, respectively, and $\mathrm{pH}$ ranged from 7.0 to 7.6. This study was conducted in accordance with the "Guidelines on the Regulation of Scientific Experiments on Animals," CPCSEA (http://cpcsea.nic.in), Govt. of India and the experimental protocols were approved by the bioethical committee of the Periyar Maniammai University (PMU/ Biotech/10.01.2009).

In total, 180 fish were randomly distributed into the four experimental groups. In each independent experimental group, 45 fish were divided into three tanks (15 fish per tank), and each tank held $200 \mathrm{~L}$ water. The following groups were maintained:

I. Control group: the fishes were fed with basal diet and kept in $\mathrm{Pb}$-free water.

II. $\mathrm{Pb}$-only group: the fishes were exposed to waterborne $\mathrm{Pb}$ $\left(1 \mathrm{mg} \mathrm{L}^{-1}\right)$ and fed with the basal diet.

III. $\mathrm{Pb}+\mathrm{P} 16$ group: the fishes were exposed to waterborne $\mathrm{Pb}$ and fed on diet supplemented with $L$. reuteri P16.

IV. P16 group: the fishes were fed on diet containing $10^{8} \mathrm{CFU} \mathrm{g}^{-1}$ of $L$. reuteri $\mathrm{P} 16$, and kept in $\mathrm{Pb}$-free water.

The experimental feeding period selected was 6 weeks. The sublethal $\mathrm{Pb}$ dose $\left(1 \mathrm{mg} \mathrm{L}^{-1}\right)$ was chosen based on earlier reports $(14,18)$. The fishes were fed experimental diets at $3-5 \%$ of body weight two times daily (09:00 and 18:00 h). For Pb-treated groups, water was exchanged with $\mathrm{Pb}$-containing water every 2 days to maintain a constant $\mathrm{Pb}$ level. For other groups, $20 \%$ of the water was exchanged daily, and $100 \%$ of the water was exchanged once in a week. Water samples were collected daily for $\mathrm{Pb}$ level determination using a flame atomic absorption spectrophotometer.

\section{Growth Performance and Sample Collection}

The fishes were weighed at the beginning and end of the 6-week feeding trial. Growth performance [i.e., percent weight gain (PWG; grams per fish), specific growth rate (SGR), and feed conversion ratio (FCR)] and survival rates of fish were calculated using the following formula:

$$
\begin{gathered}
\mathrm{PWG}=\left(W_{t}-W_{0} / W_{0}\right) \times 100 \% \\
\mathrm{SGR}=\left[\left(\ln W_{t}-\ln W_{0}\right) / t\right] \times 100 \% \\
\mathrm{FCR}=\mathrm{FI} /\left(W_{t}-W_{0}\right)
\end{gathered}
$$

where, $W_{t}$ and $W_{0}$ are the final and initial weight of the fishes, respectively, $t$ is the duration of feeding (in days); and FI is the feed intake.

At the end of the feeding trial, the fish were starved for $24 \mathrm{~h}$ before sampling. Ten fish were collected from each tank (i.e., 10 fish $\times 3$ tanks $=30$ fish per group) and euthanized with $200 \mathrm{mg} \mathrm{L}^{-1}$ of MS-222 (Ethyl 3-aminobenzoate methanesulfonate; Sigma-Aldrich, St. Louis, MO, USA). Immediately, blood samples were collected from the caudal vein using a 2 - $\mathrm{mL}$ syringe. Pooled blood samples were divided into two aliquots: one was centrifuged $\left(4,000 \times \mathrm{g}, 10 \mathrm{~min}, 4^{\circ} \mathrm{C}\right)$ to collect serum and the other was stored in anti-coagulative tubes (EDTA-2K).

Tissue samples from gills, spleen, liver, brain, and kidney were collected from those fishes and stored in metal-free Eppendorf tubes at $-20^{\circ} \mathrm{C}$. Furthermore, intestinal samples from nine fish per group ( 3 fish $\times 3$ tanks $=9$ fish) were used for the quantification of intestinal microbiota.

\section{Hematological Parameters}

Hematological parameters, including white blood cell (WBC) count, red blood cell (RBC) count, hematocrit value (Hct, \%), and hemoglobin $(\mathrm{Hb})$ level, were measured using standard techniques. Serum total protein was estimated using a commercial kit (Abcam, India). Cholesterol level was measured calorimetrically using a commercial kit (Sigma-Aldrich, USA).

\section{Blood Biochemical Parameters}

Malondialdehyde (MDA) content was measured via barbituric acid reaction chronometry (30). Total myeloperoxidase (MPO) content in blood serum was measured using a commercial kit (Abcam, USA). Serum aspartate aminotransferase (AST), alanine aminotransferase (ALT), and alkaline phosphatase (ALP) activities were determined using the Hitachi 912 clinical chemistry automatic analyzer. Superoxide dismutase (SOD) activity was determined with an enzymatic assay method using a commercial kit (Randox, Crumlin, UK). Blood creatinine level was measured using commercial assay kit (SigmaAldrich, USA). Glutathione peroxidase (GPx) was measured with an enzymatic assay using commercial kit (Abcam, USA). Serum lysozyme activity was measured with commercial assay kit (Sigma-Aldrich). Leukocyte phagocytic activity was measured according to the method described by Dotta et al. (31). 


\section{Intestinal Enzymatic Activities and Quantification of Intestinal Microbiotia}

For this experiment, whole intestines from six fish of each group were sampled aseptically and rinsed with distilled water. Intestines were homogenized and the activity of digestive enzymes was determined. Amylase and protease activities were measured as described by Pavasovic et al. (32), and lipase activity was evaluated by using a commercial kit (Sigma-Aldrich).

The entire intestinal tract was removed aseptically $(n=9)$ from the sampled fish, washed thoroughly with sterile saline $(0.85 \% \mathrm{NaCl})$, and homogenized (Potter-Elvehjem Tissue Homogenizer, NW Kennesaw, GA, USA) to isolate the intestinal microbiological communities (33). The homogenate was serially diluted to $10^{-7}$ with sterile saline. Dilutions $(100 \mu \mathrm{L})$ were spread in triplicate onto plate count agar (PCA) and MRS agar plates. MRS cultures were incubated anaerobically $\left(5 \% \mathrm{CO}_{2}\right)$ at $37^{\circ} \mathrm{C}$ for $72 \mathrm{~h}$, while PCA cultures were incubated at $37^{\circ} \mathrm{C}$ for $24-72 \mathrm{~h}$, aerobically, for determining the total count. The viability was recorded as colony-forming units (CFU) per milliliter and cell concentration was expressed as log $\left(\mathrm{CFU} \mathrm{mL} \mathrm{mL}^{-1}\right.$ ).

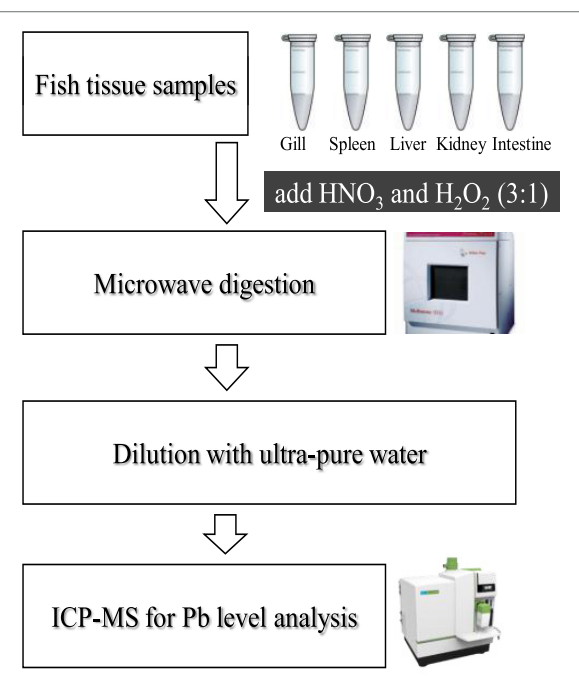

FIGURE 1 | Transfer system of tissue samples for the determination of the $\mathrm{Pb}$ level.

\section{Determination of $\mathrm{Pb}$ Level in Tissues}

Tissue samples were transferred to metal-free vessels and digested in concentrated $\mathrm{HNO}_{3}$ and $\mathrm{H}_{2} \mathrm{O}_{2}(3: 1 ; \mathrm{v} / \mathrm{v})$ using a microwave digestion system (Microwave 3000; Anton Paar GmbH, Austria) (14). The $\mathrm{Pb}$ concentrations in all the tissue samples were determined using atomic absorption spectrophotometer (PerkinElmer, USA) (Figure 1).

\section{Immune Gene Expression Analysis}

Head-kidney were dissected from six fish per group after they were anesthetized with MS-222, and total RNA was isolated from those tissues using TRIZOL reagent (Invitrogen, USA) according to the manufacturer's instructions. Real-time polymerase chain reaction analysis of IL- $1 \beta$, TNF- $\alpha$, HSP70, HSP90, and the housekeeping gene $\beta$-actin were carried out following standard protocols (29). The primer sequences and thermo cycling conditions are shown in Table 1. After amplification, melting curve analysis was performed to verify the accuracy of each amplicon. All the samples were run in parallel with the $\beta$-actin to normalize cDNA loading. Gene expression results were analyzed using the $2^{-\Delta \Delta \mathrm{CT}}$ method after verification that the primers amplified with an efficiency of approximately $100 \%$ (34).

\section{Statistical Analyses}

Independent data were obtained and statistical significance testing were performed. The homogeneity of variance was checked by analysis of variance, and chi-square test was used to analyze the data. Multiple comparisons were performed with Tukey's test to analyze the differences between independent experimental groups and treatments. All statistical analyses were performed using the OriginPro software (version 8; OriginLab Corporation, Northampton, MA, USA). Significance level was set at $P<0.05$.

\section{RESULTS}

\section{Growth Performance}

Sublethal exposure to waterborne $\mathrm{Pb}$ resulted in the inhibition of growth performance and increased the mortality of $C$. carpio (Table 2). Survival in the $\mathrm{Pb}$-exposed group was $91.1 \%$, but that in other groups was $100 \%$ and this shown by plotting KaplanMeier survival curve (Figure 2). Typical symptoms include spinal deformity and blackening of the caudal region were observed

TABLE 1 | Real-time primer sequences and thermocycling conditions.

\begin{tabular}{|c|c|c|c|}
\hline Target gene & Primer sequence $\left(5^{\prime}-3^{\prime}\right)$ & Thermocycling conditions & Reference/accession no. \\
\hline $\mathrm{TNF}-\alpha$ & $\begin{array}{l}\text { CTCAACAAGTCTCAGAACAATCAGG } \\
\text { TCCTGGTTCCTTCTCCAATCTAGCT }\end{array}$ & $95^{\circ} \mathrm{C} 30 \mathrm{~s}, 40$ cycles of $95^{\circ} \mathrm{C} 5 \mathrm{~s}, 61.1^{\circ} \mathrm{C} 30 \mathrm{~s}$, and $72^{\circ} \mathrm{C} 30 \mathrm{~s}$ & (19) \\
\hline IL-1 $1 \beta$ & $\begin{array}{l}\text { ATCTTGGAGAATGTGATCGAAGAG } \\
\text { GATACGTIITGATCCTCAAGTGTGAAG }\end{array}$ & $95^{\circ} \mathrm{C} 30 \mathrm{~s}, 40$ cycles of $95^{\circ} \mathrm{C} 5 \mathrm{~s}, 61.5^{\circ} \mathrm{C} 30 \mathrm{~s}$, and $72^{\circ} \mathrm{C} 30 \mathrm{~s}$ & (19) \\
\hline HSP70 & $\begin{array}{l}\text { GGC AGA AAG TाT GAT GAC CCA } \\
\text { GCA ATC TCC TTC ATA TTC ACC }\end{array}$ & $95^{\circ} \mathrm{C} 30 \mathrm{~s}, 40$ cycles of $95^{\circ} \mathrm{C} 5 \mathrm{~s}, 61.1^{\circ} \mathrm{C} 30 \mathrm{~s}$, and $72^{\circ} \mathrm{C} 30 \mathrm{~s}$ & $(15)$ \\
\hline HSP90 & $\begin{array}{l}\text { GGAAATCTTCCTCCGAGAGC } \\
\text { CCGAATTGACCGATCATAGA }\end{array}$ & $95^{\circ} \mathrm{C} 30 \mathrm{~s}, 40$ cycles of $95^{\circ} \mathrm{C} 5 \mathrm{~s}, 61.1^{\circ} \mathrm{C} 30 \mathrm{~s}$, and $72^{\circ} \mathrm{C} 30 \mathrm{~s}$ & $(28)$ \\
\hline$\beta$-actin & $\begin{array}{l}\text { GACTTCGAGCAGGAGATGG } \\
\text { CAAGAAGGATGGCTGGAACA }\end{array}$ & $95^{\circ} \mathrm{C} 30 \mathrm{~s}, 40$ cycles of $95^{\circ} \mathrm{C} 5 \mathrm{~s}, 62.4^{\circ} \mathrm{C} 30 \mathrm{~s}$, and $72^{\circ} \mathrm{C} 30 \mathrm{~s}$ & $(19)$ \\
\hline
\end{tabular}


TABLE 2 | Effect of dietary supplementation on growth performance of Cyprinus carpio during 6-week trial.

\begin{tabular}{|c|c|c|c|c|c|c|}
\hline Group & Initial weight (g) & Final weight (g) & PWG (\%) & SGR (\%) & FCR & Survival (\%) \\
\hline Control & $23.26 \pm 0.38^{a}$ & $32.86 \pm 1.07^{a}$ & $37.61 \pm 1.26^{\mathrm{a}}$ & $0.90 \pm 0.2^{a}$ & $2.04 \pm 0.08^{a}$ & 100 \\
\hline $\mathrm{Pb}$ only & $23.21 \pm 0.71^{a}$ & $29.73 \pm 1.14^{b}$ & $30.11 \pm 0.82^{b}$ & $0.71 \pm 0.03^{b}$ & $2.47 \pm 0.13^{b}$ & 91.1 \\
\hline $\mathrm{Pb}+\mathrm{P} 16$ & $23.14 \pm 0.63^{a}$ & $30.91 \pm 1.52^{\mathrm{b}}$ & $33.26 \pm 0.64^{b}$ & $0.83 \pm 0.07^{b}$ & $2.28 \pm 0.13^{c}$ & 100 \\
\hline P16 only & $23.18 \pm 0.52^{a}$ & $36.0 .8 \pm 0.96^{c}$ & $54.76 \pm 1.77^{c}$ & $1.22 \pm 0.6^{c}$ & $1.84 \pm 0.6^{d}$ & 100 \\
\hline
\end{tabular}

PWG, percent weight gain; SGR, specific growth rate; FCR, feed conversion ratio.

Values in the same column with different superscript small letters are significantly different $(P<0.05)$.

Values are presented as mean $\pm S D$ ( $n=45$ fish in each group).

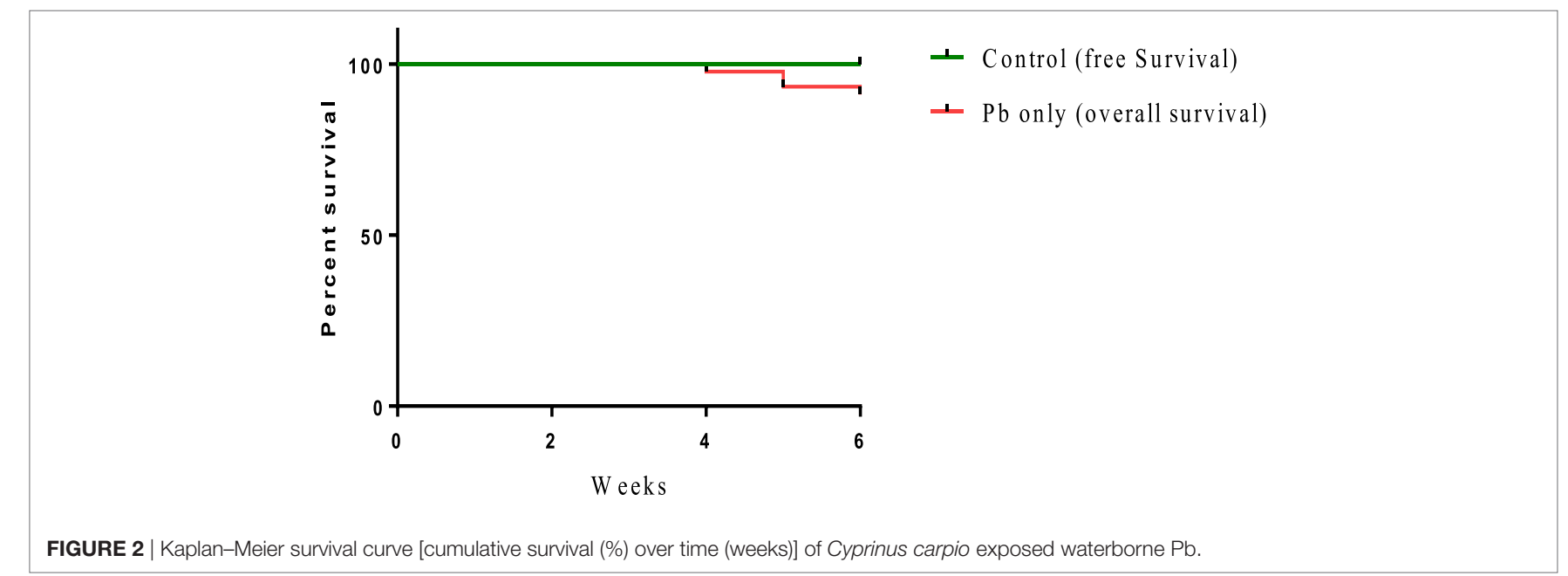

TABLE 3 | Effect of Lactobacillus reuteri P16 supplementation on the hematological parameters of Cyprinus carpio.

\begin{tabular}{|c|c|c|c|c|c|c|}
\hline \multirow[t]{2}{*}{ Group } & \multicolumn{6}{|c|}{ Parameters } \\
\hline & $\mathrm{RBC}\left(\times 10^{6} \mathrm{~mm}^{-3}\right)$ & WBC $\left(\times 10^{3} \mathrm{~mm}^{-3}\right)$ & Hct (\%) & $\mathrm{Hb}\left(\mathrm{g} \mathrm{dL}^{-1}\right)$ & Total protein $\left(\mathrm{g} \mathrm{dL}^{-1}\right)$ & Cholesterol (mg dL-1) \\
\hline Control & $1.69 \pm 0.07^{\mathrm{ac}}$ & $4.21 \pm 0.13^{a}$ & $24.03 \pm 0.83^{a}$ & $5.37 \pm 0.13^{a}$ & $2.87 \pm 0.04^{a}$ & $58.06 \pm 2.8^{a}$ \\
\hline $\mathrm{Pb}$ only & $1.53 \pm 0.08^{b}$ & $3.48 \pm 0.09^{b}$ & $19.86 \pm 1.07^{b}$ & $3.89 \pm 0.11^{b}$ & $2.41 \pm 0.07^{b}$ & $63.57 \pm 2.4^{b}$ \\
\hline $\mathrm{Pb}+\mathrm{P} 16$ & $1.58 \pm 0.05^{\mathrm{ba}}$ & $3.96 \pm 0.14^{\mathrm{ab}}$ & $21.92 \pm 0.74^{b}$ & $4.92 \pm 0.08^{a}$ & $2.78 \pm 0.06^{\mathrm{ba}}$ & $61.19 \pm 3.3^{\mathrm{ba}}$ \\
\hline P16 only & $1.76 \pm 0.09^{\circ}$ & $4.54 \pm 0.11^{\mathrm{a}}$ & $25.13 \pm 1.28^{\mathrm{a}}$ & $6.08 \pm 0.14^{c}$ & $3.62 \pm 0.11^{c}$ & $57.88 \pm 3.02^{\mathrm{a}}$ \\
\hline
\end{tabular}

RBC, red blood cell; WBC, white blood cell; Hct, hematocrit; Hb, hemoglobin.

Data are presented as mean $\pm S D$ ( $n=30$ fish from each group). Means in the same column with different superscript small letters are significantly different ( $P<0.05)$.

in fish exposed to $\mathrm{Pb}$ only. Final weight gain (FWG), PWG, and $\mathrm{SGR}$ were significantly lowered in the $\mathrm{Pb}$-only group than in the control group or the group fed with $L$. reuteri P16 alone. The FCR value was significantly higher in $\mathrm{Pb}$-only group, but dietary supplementation with $L$. reuteri P16 decreased the FCR value, and it was the lowest in the group fed with L. reuteri P16 only. Supplementation with $L$. reuteri P16 prevented death caused by $\mathrm{Pb}$ exposure, as revealed by $100 \%$ survival in the $\mathrm{Pb}+\mathrm{P} 16$ group. Growth performance (FWG, PWG, and SGR) in the Pb + P16 group was not significantly higher than that of the $\mathrm{Pb}$-only group. However, administration of $L$. reuteri P16 alone significantly increased the FG, PWG, and SGR of the fishes, when compared with the other groups. FCR was the lowest in the P16 group (Table 2).

\section{Hematological Parameters}

$\mathrm{Pb}$ exposure significantly decreased the RBC, WBC, Hct, Hb, and total protein level in blood, when compared with those in the control (Table 3). However, decreases of those parameters were reversed by $L$. reuteri $\mathrm{P} 16$ supplementation. Levels of RBC, $\mathrm{WBC}, \mathrm{Hb}, \mathrm{Hct}$, and total protein recovered in the $\mathrm{Pb}+\mathrm{P} 16$ group, and the differences with the control group were not significant. Furthermore, blood cholesterol level, which increased significantly under $\mathrm{Pb}$-exposure stress, was recovered by probiotic feeding (Table 3). However, supplementation with $L$. reuteri P16 alone had no significant effect on these parameters, except total protein level, which was significantly increased by probiotic supplementation.

\section{Blood Biochemical Parameters}

Among biochemical parameters, levels of AST $\left(163.1 \pm 4.7 \mathrm{U} \mathrm{mL}^{-1}\right)$, $\operatorname{ALT}\left(68.41 \pm 2.12 \mathrm{U} \mathrm{mL}^{-1}\right)$, and creatinine $\left(0.37 \pm 0.07 \mathrm{U} \mathrm{mL}^{-1}\right)$ increased significantly in $(P<0.05)$ in $\mathrm{Pb}$-only group, but these alterations were reversed to the normal level in $\mathrm{Pb}+\mathrm{P} 16$ group (Table 4). However, feeding with $L$. reuteri $\mathrm{P} 16$ alone had no significant effect on those parameters, except AST level, which 
TABLE 4 | Effect of Lactobacillus reuteri P16 supplementation on the blood biochemical parameters of Cyprinus carpio

\begin{tabular}{|c|c|c|c|c|c|}
\hline \multirow[t]{2}{*}{ Group } & \multicolumn{5}{|c|}{ Parameters } \\
\hline & ALP (IU L-1) & AST (U mL-1) & ALT (U mL-1) & MPO (U L-1) & Creatinine $\left(\mathrm{mg} \mathrm{dL}^{-1}\right)$ \\
\hline Control & $21.38 \pm 1.26^{\mathrm{a}}$ & $104.3 \pm 3.4^{a}$ & $32.06 \pm 1.46^{\mathrm{a}}$ & $34.68 \pm 1.83^{\mathrm{a}}$ & $0.26 \pm 0.08^{\mathrm{ac}}$ \\
\hline $\mathrm{Pb}$ only & $17.82 \pm 1.14^{\mathrm{b}}$ & $163.1 \pm 4.7^{b}$ & $68.41 \pm 2.12^{\mathrm{b}}$ & $29.57 \pm 1.24^{b}$ & $0.37 \pm 0.07^{b}$ \\
\hline $\mathrm{Pb}+\mathrm{P} 16$ & $20.87 \pm 0.83^{a}$ & $107.6 \pm 2.8^{a}$ & $39.6 \pm 1.38^{\circ}$ & $32.92 \pm 1.67^{a}$ & $0.29 \pm 0.08^{a}$ \\
\hline P16 only & $22.04 \pm 1.06^{\mathrm{a}}$ & $98.9 \pm 3.1^{c}$ & $31.33 \pm 1.6^{a}$ & $37.14 \pm 0.92^{c}$ & $0.24 \pm 0.03^{c}$ \\
\hline
\end{tabular}

ALP, alkaline phosphatase; AST, aspartate aminotransferase; ALT, alanine aminotransferase; MPO, myeloperoxidase.

Values in the same column with different superscript small letters are significantly different $(P<0.05)$.

values are presented as mean $\pm S D(n=30)$.

decreased significantly in this group, as compared with that in the control. Furthermore, serum ALP and MPO levels, which decreased significantly in $\mathrm{Pb}$-only group, were recovered in the $\mathrm{Pb}+\mathrm{P} 16$ group, but these levels were slightly lower than those in the control group. However, L. reuteri P16 treatment alone significantly increased the MPO level than that in the control or other groups. In case of MPO level, L. reuteri P16 treatment alone had no significant effect on it.

\section{Serum Oxidative Parameters}

Malondialdehyde level was increased significantly $(P<0.05)$ in the $\mathrm{Pb}$-only group, but $L$. reuteri $\mathrm{P} 16$ treatment reversed the MDA level to the normal range (Figure 3 ). $\mathrm{Pb}$ exposure reduced the level of GPx and SOD in fish significantly $(P<0.05)$, but levels of GPx and SOD recovered in the $\mathrm{Pb}+\mathrm{P} 16$ group. However, dietary supplementation of $L$. reuteri $\mathrm{P} 16$ alone had no significant effect on those parameters, except SOD level, which increased significantly than that in the others.

\section{Lysozyme and Phagocytic Activities}

$\mathrm{Pb}$ exposure caused a profound decline in innate immune parameters, such as serum lysozyme and phagocytic activities (Figure 4). However, dietary administration of L. reuteri P16 helped in recovering lysozyme and phagocytic activities, as evident in the $\mathrm{Pb}+\mathrm{P} 16$ group. Moreover, dietary administration of $L$. reuteri $\mathrm{P} 16$ only markedly increased $(P<0.05)$ lysozyme (27.5 $\mathrm{U} \mathrm{mL}^{-1}$ ) and phagocytic activities (18.68\%), when compared with those in the control or any other group (Figure 4).

\section{Intestinal Enzymatic Activities}

Intestinal enzymatic activities are shown in Figure 5. Activities of amylase, protease, and lipase declined in the $\mathrm{Pb}$-exposed group, and the differences were significant only in case of amylase activity. The alterations of amylase and protease activities were significantly reversed in the $\mathrm{Pb}+\mathrm{P} 16$ group. The lipase activity was slightly recovered in $\mathrm{Pb}+\mathrm{P} 16$ group. Furthermore, dietary administration of $L$. reuteri P16 only resulted in significantly higher amylase (1.49 $\mathrm{U} \mathrm{mg}^{-1}$ protein) and protease $\left(3.43 \mathrm{U} \mathrm{mg}^{-1}\right.$ protein) activities, when compared with that in the control group. However, L. reuteri P16 only had no significant effects on lipase activity.

\section{Quantification of Intestinal Microbiota}

$\mathrm{Pb}$ exposure caused a profound decline in gut microbial diversity (Figure 6). Population of total bacteria and LAB counts decreased
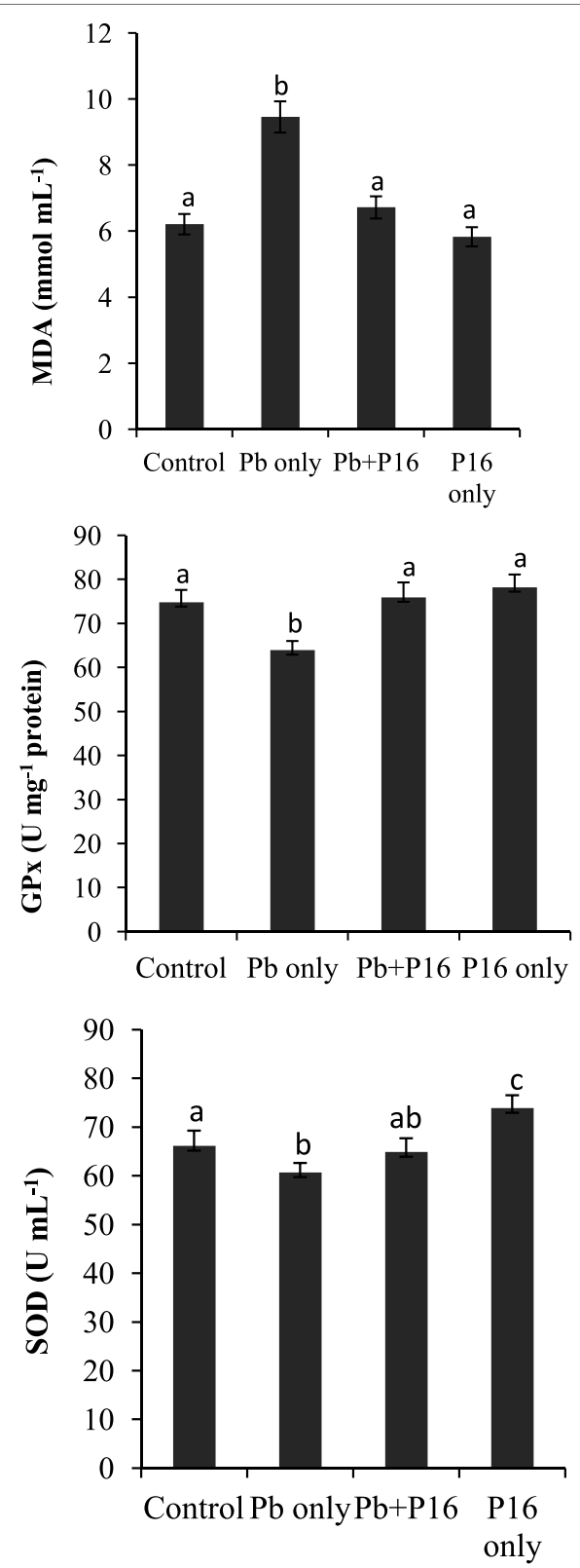

FIGURE 3 | Influence of Lactobacillus reuteri P16 supplementation on the oxidative parameters in the blood of Cyprinus carpio. Significant differences between groups are indicated with different superscript letters. Results are presented as mean \pm SEM $(n=30)$. 

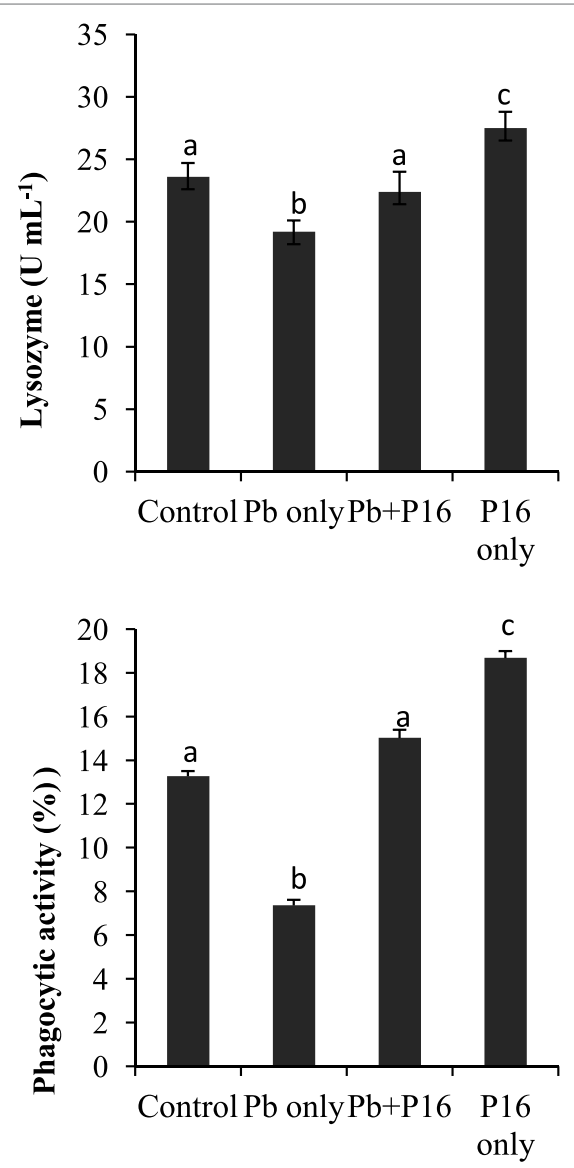

FIGURE 4 | Effect of Lactobacillus reuteri P16 supplementation on the serum lysozyme and leukocyte phagocytoc activities of Cyprinus carpio. Significant differences between groups are indicated with different superscript letters.

Results are presented as mean $\pm \operatorname{SEM}(n=30)$.

significantly in $\mathrm{Pb}$-only group, as compared with that of the other groups. However, probiotic treatment had considerable effect on intestinal microbiota. Alterations of bacterial population were reversed in the $\mathrm{Pb}+\mathrm{P} 16$ group. Moreover, L. reuteri $\mathrm{P} 16$ treatment increased the LAB population significantly in L. reuteri P16-treated group.

\section{$\mathrm{Pb}$ Levels in Tissues}

$\mathrm{Pb}$ levels detected in various tissues of carps are shown in Table 5. $\mathrm{Pb}$ exposure significantly increased the level of $\mathrm{Pb}$ in gills $\left(5.17 \mu \mathrm{g} \mathrm{g}^{-1}\right)$, spleen $\left(3.86 \mu \mathrm{g} \mathrm{g}^{-1}\right)$, liver $\left(8.92 \mu \mathrm{g} \mathrm{g} \mathrm{g}^{-1}\right)$, kidney $\left(26.33 \mu \mathrm{g} \mathrm{g}^{-1}\right)$, and intestines $\left(10.27 \mu \mathrm{g} \mathrm{g}^{-1}\right)$, when compared with those in the control group. Supplementation with L. reuteri $\mathrm{P} 16$ significantly decreased $\mathrm{Pb}$ accumulation in all tissue, except the intestine, when compared with the $\mathrm{Pb}$-only group. But, the level of $\mathrm{Pb}$ accumulation in the $\mathrm{Pb}+\mathrm{P} 16$ group was higher $(P<0.05)$ than that in the control group. Furthermore, $\mathrm{Pb}$ accumulation in the gills, spleen, liver, kidney, and intestine of the P16 group was $0.011,0.05,0.19,0.28$, and $0.09 \mu \mathrm{g} \mathrm{g}^{-1}$, respectively, which were significantly lower than those in the $\mathrm{Pb}+\mathrm{P} 16$ group, but no significant differences were observed with those in the control group.
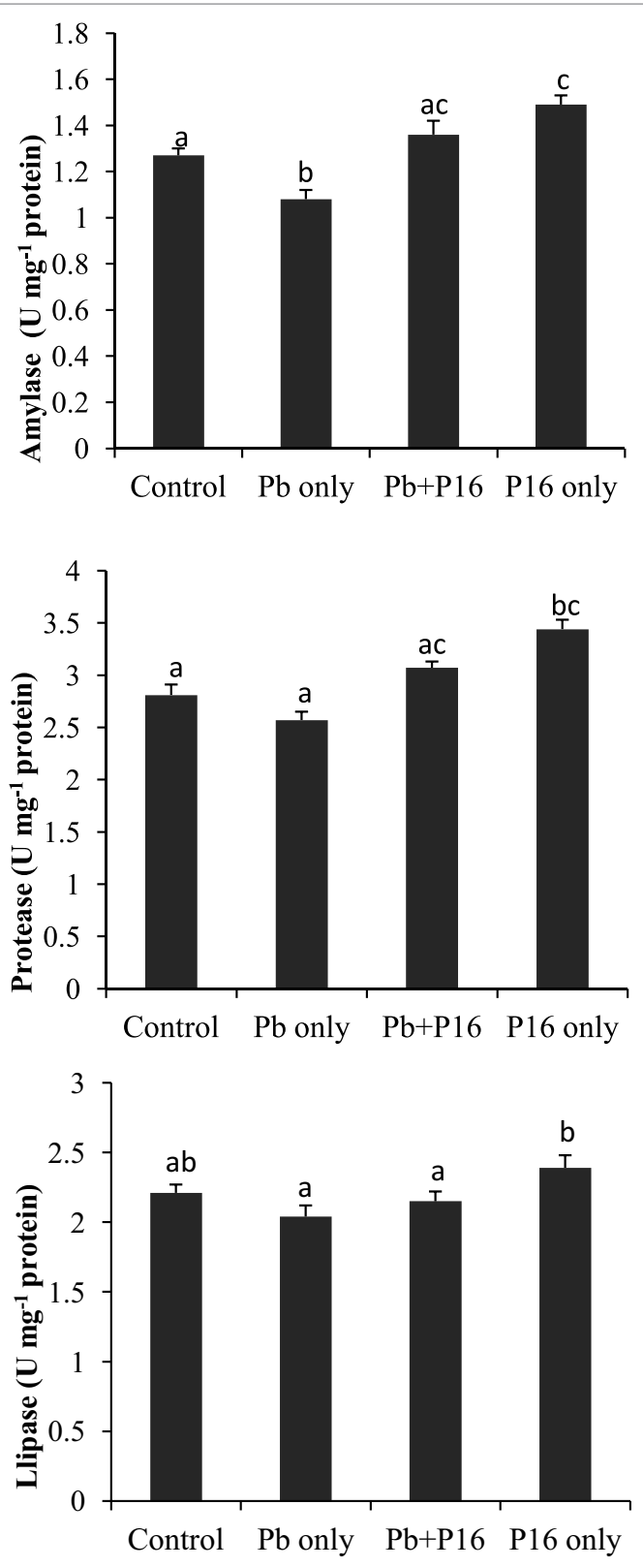

FIGURE 5 | Influence of Lactobacillus reuteri P16 supplementation on the intestinal enzymatic activities of Cyprinus carpio. Significant differences between groups are indicated with different superscript letters. Results are presented as mean $\pm \operatorname{SEM}(n=6)$.

\section{Immune Gene Expression}

Expression profiles of TNF- $\alpha$, IL-1 $\beta$, HSP70, and HSP90 in the head-kidney of the fishes at the end of the trial (Figure 7) showed that the expression of the pro-inflammatory cytokine TNF- $\alpha$ was significantly lower than that in the group exposed to $\mathrm{Pb}$ only, but it reversed in the $\mathrm{Pb}+\mathrm{P} 16$ group. Similarly, IL-1 $\beta$ expression, which was lower in $\mathrm{Pb}$-only group, was reversed in the $\mathrm{Pb}+\mathrm{P} 16$ group. However, expression of TNF- $\alpha$ was significantly higher in the P16 group when compared with that in any other group. 
The mRNA expression of heat shock proteins (HSP70 and HSP90) was increased drastically in Pb-only exposed group, but probiotic supplementation reversed the expression to the normal level (Figure 7). Interestingly, dietary administration of $L$. reuteri P16 only decreased the expression of both HSPs, but the differences remained significant in case of HSP70.

\section{DISCUSSION}

Physiological status of fishes is an important factor for determining their ability to resist pathogen attacks. Fish growth
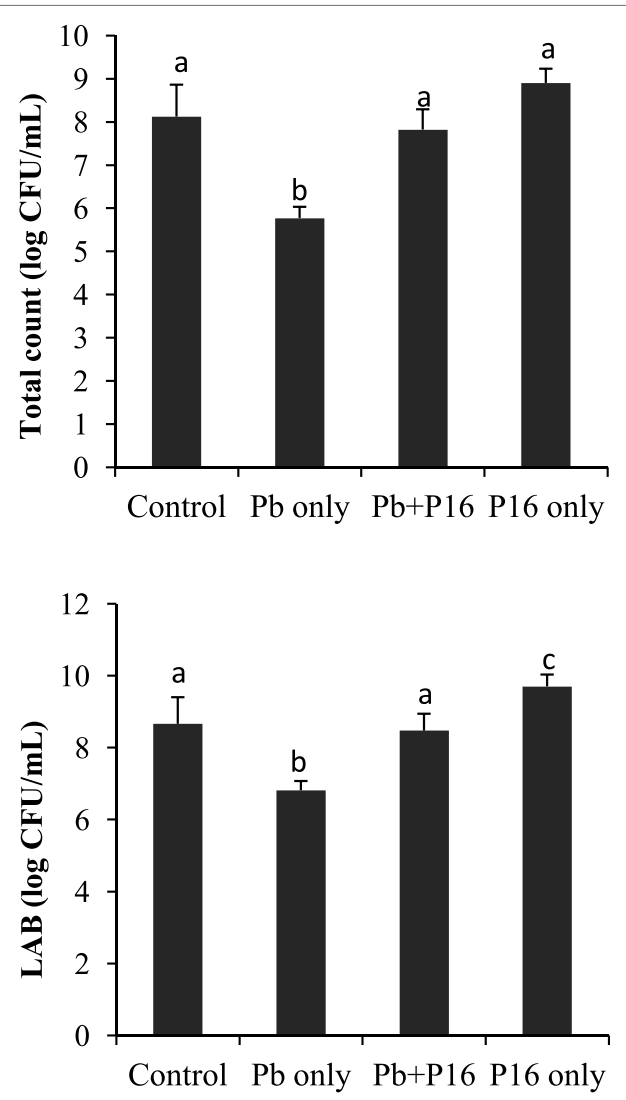

FIGURE 6 | Effect of waterborne Pb exposure and dietary Lactobacillus reuteri P16 on gut bacterial population of Cyprinus carpio. The different superscript letters indicate statistically significant differences between groups. Results are expressed as mean $\pm \operatorname{SD}(n=6)$. performance is affected by various external factors, such as temperature, nutrition, and toxicants. Inhibition of fish growth could be induced by physiological stress during exposure to toxic substances, because stress can reduce food consumption or assimilation (35). L. reuteri $\mathrm{P} 16$ supplementation reversed the $\mathrm{Pb}$-exposure induced adverse effects on growth performance and survival of C. carpio. Recently, Zhai et al. (18) demonstrated that dietary supplementation with L. plantarum ameliorated the growth performance and prevented the death of $\mathrm{Pb}$-exposed Nile tilapia (Oreochromis niloticus). Moreover, dietary supplementation with L. plantarum CCFM8610 increased the growth rate, decreased the FCR, and completely prevented the death of Cd-exposed fish (14). Also, significantly lower FCR in the P16 group reveals the fact that carp consumed dietary nutrients more efficiently when feed was supplemented with L. reuteri, which was consistent with numerous studies that reported significantly higher growth performances in fish fed with diet supplemented with the probiotic Lactobacillus (24).

Hematology has been widely used to evaluate the health status of animals exposed to environmental toxicants, and it provides information on digestive function, nutrient status, and metabolic activity of fish (36). The significant reduction in hematological parameters, such as $\mathrm{RBC}$, WBC, Hct, and $\mathrm{Hb}$ concentration after waterborne $\mathrm{Pb}$ exposure was consistent with earlier reports (4). Heavy metal exposure generally induces lysis of erythrocytes in aquatic animals, leading to the depletion of Hct and $\mathrm{Hb}$ (37). Lead directly inhibits the synthesis of $\mathrm{Hb}$ by inhibiting various key enzymes involved in the heme synthesis pathway and reduces the life span of RBCs by increasing the fragility of cell membranes. The combined effect of these two processes leads to anemia (38). However, dietary L. reuteri P16 was effective in recovering those hematological parameters. The increased of RBC and WBC may be attributed to the effective antioxidant role of $L$. reuteri $\mathrm{P} 16$ (discussed below). Serum total protein, an important indicator of humoral immune system and health status of fish, was recovered in $\mathrm{Pb}+\mathrm{P} 16$ group. Increase in serum protein level might be partially related with higher WBC, which is a major source of serum protein production (36). Furthermore, improved protein level in the group fed with $L$. reuteri P16 only indicated improved health status of fishes owing to probiotic supplementation.

Hepatocellular injury in fish may be attributed to stress, nutrition imbalance, diseases, or pollutants. AST and ALT levels are biological indicators of hepatic health status (39). The restoration of serum AST and ALT levels in the $\mathrm{Pb}+\mathrm{P} 16$ group indicated the protective effect of $L$. reuteri $\mathrm{P} 16$ against $\mathrm{Pb}$-induced damage

TABLE 5 | Effect of Lactobacillus reuteri P16 supplementation on the Pb levels in the tissues of Cyprinus carpio.

\begin{tabular}{|c|c|c|c|c|c|}
\hline \multirow[t]{2}{*}{ Group } & \multicolumn{5}{|c|}{ Concentration of $\mathrm{Pb}$ in tissues ( $\mu \mathrm{g} \mathrm{g}^{-1}$ of wet tissue) } \\
\hline & Gill & Spleen & Liver & Kidney & Intestine \\
\hline Control & $0.014 \pm 0.001^{\mathrm{a}}$ & $0.07 \pm 0.01^{\mathrm{a}}$ & $0.24 \pm 0.02^{\mathrm{a}}$ & $0.37 \pm 0.08^{a}$ & $0.11 \pm 0.02^{\mathrm{a}}$ \\
\hline $\mathrm{Pb}$ only & $5.17 \pm \pm 0.13^{b}$ & $3.86 \pm 0.07^{b}$ & $8.92 \pm 0.13^{b}$ & $26.33 \pm 2.28^{b}$ & $10.27 \pm 0.36^{b}$ \\
\hline $\mathrm{Pb}+\mathrm{P} 16$ & $2.94 \pm 0.14^{c}$ & $2.11 \pm 0.08^{c}$ & $5.73 \pm 0.26^{c}$ & $17.08 \pm 1.17^{\circ}$ & $8.92 \pm 0.61^{b}$ \\
\hline P16 only & $0.011 \pm 0.001^{\mathrm{a}}$ & $0.05 \pm 0.01^{a}$ & $0.19 \pm 0.03^{a}$ & $0.28 \pm 0.03^{a}$ & $0.09 \pm 0.004^{a}$ \\
\hline
\end{tabular}

Values in the same column with different superscript small letters are significantly different $(P<0.05)$.

Values are presented as mean $\pm S D$ ( $n=30$ fish in each group). 

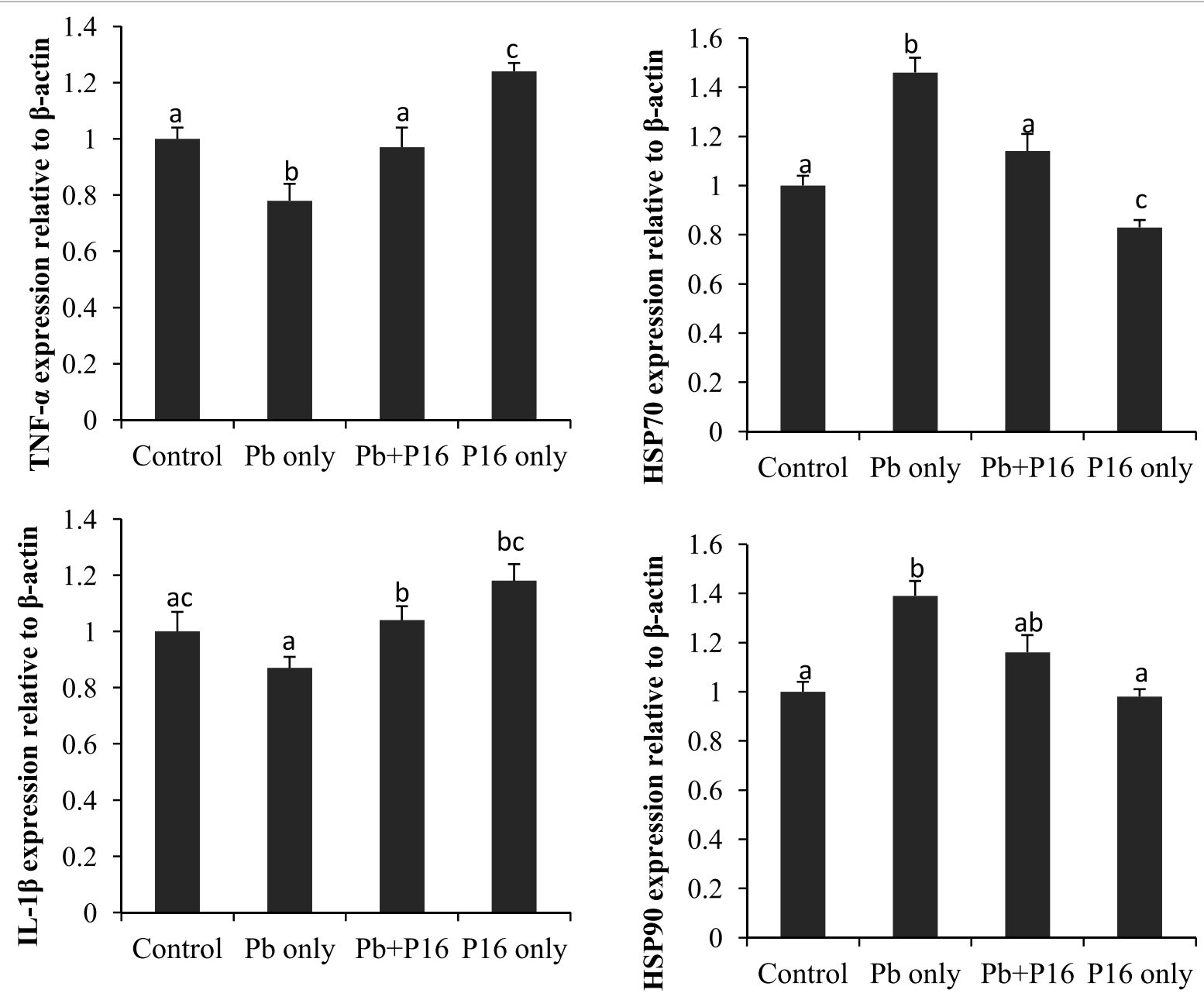

FIGURE 7 | Effects of dietary administration of Lactobacillus reuteri P16 on the relative mRNA expression levels of TNF- $\alpha$, IL-1 $\beta$, HSP70, and HSP90 in the head-kidney of Cyprinus carpio.

of liver and heart in C. carpio (40). Recently, Zhai et al. $(14,18)$ demonstrated that dietary administration of L. plantarum could restore alterations of AST and ALT in Nile tilapia. Similarly, changes in ALP activity, which an indicator of environmental stress, was restored in $\mathrm{Pb}+\mathrm{P} 16$ group. However, diet-borne $\mathrm{Pb}$ exposure had no significant effect on ALP activity in rockfish (Sebastes schlegelii) (4). Cholesterol is a critical structural component of membranes and a precursor of all steroid hormones. The increase in cholesterol level in the $\mathrm{Pb}$ exposure group may be a sensitive indicator for metal-induced environmental stress (41). The blood cholesterol level was revered by dietary L. reuteri P16 supplementation. A considerable increase in the cholesterol of Nile tilapia (42) and rockfish (4) exposed to $\mathrm{Pb}$ was reported. Furthermore, creatinine level, which is an indicator of kidney function, is normally presents in low quantities in fishes (43). However, higher levels were present in the $\mathrm{Pb}$-only group. Therefore, the higher cholesterol level in blood may be due to liver and kidney damage.

Malondialdehyde, GPx, and SOD are biomarkers of heavy metal-induced oxidative stress in aquatic animals. MDA, the main component of lipid peroxides, has strong biotoxicity and can damage the structure and function of cells (44). The first line of defense against oxidative stress consists of the antioxidant enzymes SOD, CAT, and GPx, which convert superoxide radicals into hydrogen peroxide and then into water and molecular oxygen (45). SOD comprises a group of metalloenzymes that catalyzes the dismutation of superoxide to hydrogen peroxide and plays a crucial role against the toxic effects of superoxide radicals in aerobic organisms (46). In this study, higher oxidative stress in the $\mathrm{Pb}$ exposure group was manifested by higher $(P<0.05)$ MDA levels and lower $(P<0.05)$ GPx and SOD levels. However, $L$. reuteri $\mathrm{P} 16$ supplementation reduced oxidative stress in carp. This study indicates that $L$. reuteri P16 can directly mitigate $\mathrm{Pb}$-induced oxidative stress. Recently, Zhai et al. $(14,18)$ demonstrated that dietary supplementation of L. plantarum could reduce waterborne $\mathrm{Pb}$-induced oxidative stress in Nile tilapia. Those results, together with those of the present study, indicate that probiotic lactobacilli have protective effects against $\mathrm{Pb}$-induced oxidative damage in fish. MPOs are known to play an important role in cellular defenses against 
various bacterial infections and can generates oxidants from $\mathrm{H}_{2} \mathrm{O}_{2}$ and a range of co-substrates (47). Recently, Paul et al. (8) reported that exposure to lead acetate could significantly reduce MPO levels in the macrophages of the freshwater fish C. punctatus. Dietary L. reuteri P16 supplementation was effective in recovering the MPO level in $\mathrm{Pb}$-exposed fish and thereby improving host defense mechanisms.

Fish generally depend on non-specific immune responses. Lysozymes constitute the first line of defense following immune challenge to inhibit the adhesion and colonization of microorganisms (36); they split the $\beta-1,4$ glycosidic linkages between the $N$-acetyl glucosamine and $N$-acetyl muramic acid of the peptidoglycan in the bacterial cell wall, causing bacteriolysis and thereby controlling infection. By contrast, phagocytosis is responsible for early activation of the inflammatory response before antibody production and is mediated by phagocytic cells, such as neutrophils, monocytes, and macrophages, in fish (48). Significantly lower phagocytic and lysozyme activity $\mathrm{r}$ in the $\mathrm{Pb}$-exposed group was in line with earlier reports $(8,18)$. But, those activities were recovered in the $\mathrm{Pb}+$ L. reuteri $\mathrm{P} 16$ supplementation group. Several studies have demonstrated that probiotic feeding could significantly improve various innate immune parameters in fish $(22,24,25)$.

Another possible explanation for the stimulation of growth by potential probiotic $L$. reuteri $\mathrm{P} 16$ may be related to the induction of the expression of digestive enzymes in carp intestines by dietary P16, which boosts the natural digestive enzyme activity, and thereby the growth performance, of the host (49). This increased digestive enzymatic activity might be a means of protection against the adverse effects of $\mathrm{Pb}$ on fish. Very recently, Zhai et al. (18) reported that dietary administration of probiotic L. plantarum increased amylase and protease activity in Nile tilapia exposed to waterborne $\mathrm{Pb}$. Better feed consumption (as revealed by reduced FCR) and digestion in L. reuteri P16 supplemented groups may be related to increased digestive enzyme activity and thereby increased appetite in fish. The gut microbiota is in direct contact with the intestinal mucosa constantly and plays a vital role in maintaining fish health (50). Pb exposure decreased $\mathrm{LAB}$ counts and total gut microbial populations. $\mathrm{Pb}$-induced alterations in the gut microbiota may cause dysbiosis in carps, which can be related to the adverse effects on growth performance, antioxidant defense system, and hematological parameters of $\mathrm{Pb}$-exposed fish. However, dietary supplementation with L. reuteri P16 moderately restored the gut dysbiosis. L. reuteri $\mathrm{P} 16$ supplementation increased $\mathrm{LAB}$ population in $\mathrm{Pb}$-exposed fish. Alleviation of heavy metal-induced toxicities in fish through dietary administration of lactobacilli strains has been reported $(13,14,18)$. Moreover, increased population of LAB may enhance $\mathrm{Pb}$ sequestration in gut, owing to its cellular accumulation and bioremoval.

Tissue-specific accumulation can be a sensitive indicator of metal exposure in aquatic toxicology. Exposure to waterborne $\mathrm{Pb}$ causes significant accumulation of $\mathrm{Pb}$ in various tissues of carp, with highest accumulation in kidney. Exposure of $S$. schlegelii to dietary $\mathrm{Pb}$ revealed that the highest $\mathrm{Pb}$ accumulation took place in the kidney (8). Similarly, varying $\mathrm{Pb}$ accumulation was recorded in tissues of Nile tilapia exposed to waterborne $\mathrm{Pb}$ (18). Differences in the extent of metal accumulation between tissues are considerably related to ecological needs and metabolic activity (51). The uptake of toxic heavy metals in aquatic animals generally occurs via two major routes: waterborne and diet borne. Waterborne $\mathrm{Pb}$ can be taken up by gills of fish, and it may contaminate food and be absorbed via intestines, then accumulate in tissues including the kidneys and liver (52). L. reuteri P16 used in this study has been reported to bind effectively to $\mathrm{Pb}$ in vitro (28). Therefore, intestinal L. reuteri $\mathrm{P} 16$ could bind secreted $\mathrm{Pb}$ before re-absorption from intestines, which increases $\mathrm{Pb}$ excretion through the feces of fish and inhibits intestinal absorption (22). This may a reason for the reduction in $\mathrm{Pb}$ levels in the $\mathrm{Pb}+$ L. reuteri $\mathrm{P} 16$ group.

The inflammatory response is a key element in the innate immune response system and is primarily mediated by cytokines (53). Very little is known about the immunotoxicology of heavy metals at the genetic level in fish. The cytokines IL-1 $\beta$ and TNF- $\alpha$ are primarily produced by monocytes and macrophages and regulate multiple aspects of the immune response. TNF- $\alpha$ affects tissue vasculature in inflammation and also induces acute phase proteins from the liver (54). The observed downregulation of TNF- $\alpha$ and IL- $1 \beta$ implicates NF- $\kappa B$ signaling pathway. However, $L$. reuteri $\mathrm{P} 16$ supplementation had a positive on TNF- $\alpha$ and IL-1 $\beta$ expression. In a previous study, Paul et al. (8) recorded decreased TNF- $\alpha$ level in sera and cell lysates of freshwater fish C. punctatus exposed to lead acetate. Based on the results of this study, it can be stated that $\mathrm{Pb}$ renders the fish in an immunocompromised and inflammatory state. Thus, TNF- $\alpha$ and IL- $1 \beta$ are downregulated, probably by the action of the heavy metal (8), but probiotic supplementation reversed these effects on the expression of those genes.

The synthesis of heat shock proteins (Hsps) increases in response to various physical and chemical stressors, including temperature and metal stress, and consequently these proteins can be good environmental stress biomarkers (55). Expression of HSPs which increased in $\mathrm{Pb}$-exposure group, was further decreased in the L. reuteri P16 supplementation group and thus alleviated stress condition in fish. In agreement with the results of our study, Mohapatra et al. (19) demonstrated that dietary supplementation of a probiotic mixture consisting of Bacillus subtilis, Lactococcus lactis, and Saccharomyces cerevisiae decreased the expression of HSP70 in Labeo rohita. Stress-reducing factors produced by probiotics might have lowered the HSP levels in fish, reduced $\mathrm{Pb}$-induced stress, and resulted in better growth and immunity.

Interestingly, co-treatment with $\mathrm{Pb}$ and $L$. reuteri $\mathrm{P} 16$ reversed $\mathrm{Pb}$-induced adverse effects on the carp species studied. The potential beneficial effects and protection by probiotics against $\mathrm{Pb}$ toxicity in carp has been shown in Figure 8. The hematological parameters indicated the ability of $L$. reuteri P16 to stimulate erythropoiesis, thereby increasing the oxygen transport, and a similar result had been reported earlier (13). Previously, we have demonstrated the excellent $\mathrm{Pb}$-binding ability of this strain (28). Therefore, supplementing diets with this strain can reduce intestinal absorption of $\mathrm{Pb}$ and reduce $\mathrm{Pb}$ accumulation in other tissues. The strain L. reuteri P16 possess strong antioxidant abilities (28). In this study, co-treatment with $\mathrm{Pb}$ and $L$. reuteri $\mathrm{P} 16$ reduced 


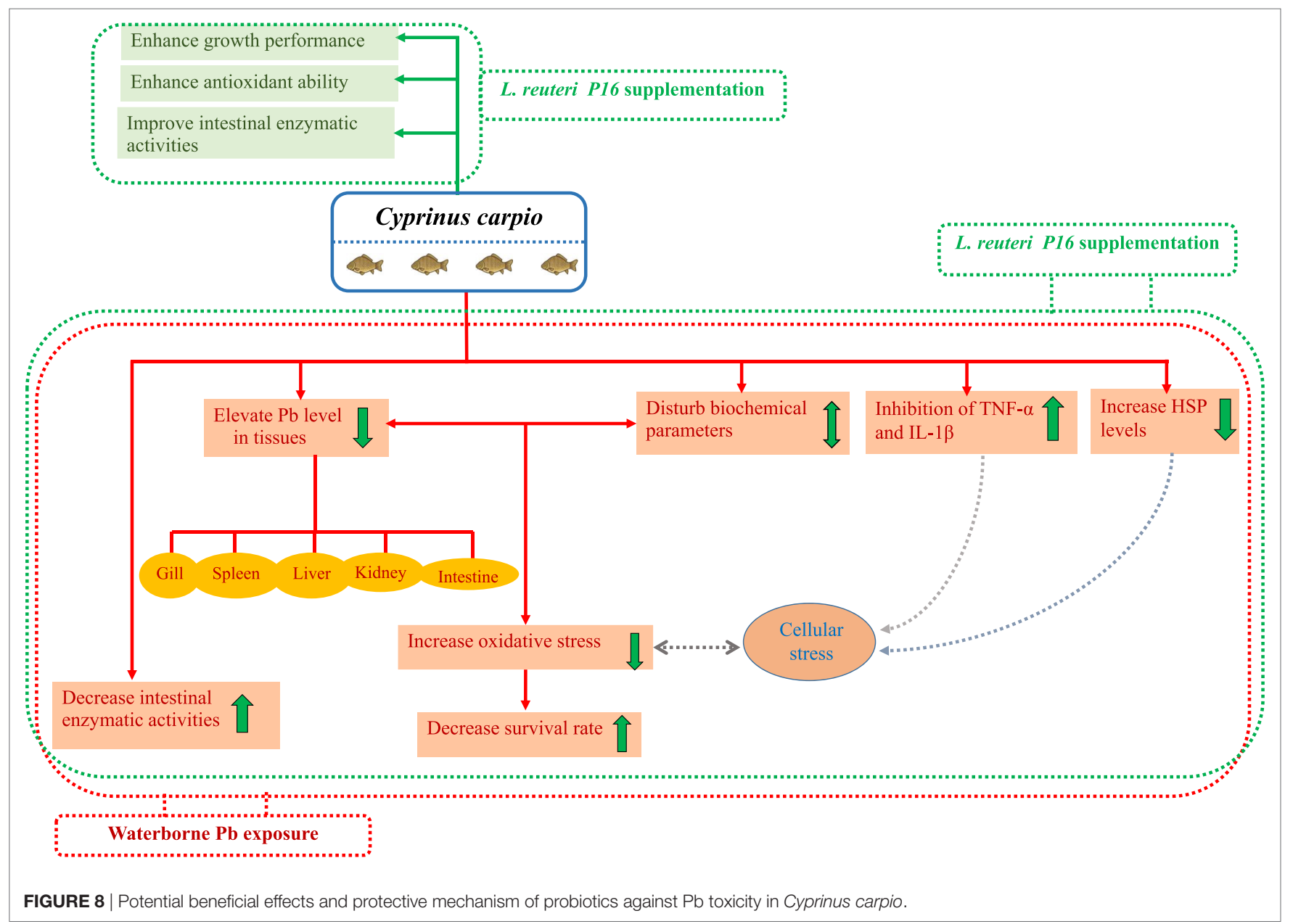

production of MDA and increased the activities of antioxidant enzymes (SOD and GPx). Thus, L. reuteri P16 alleviates the $\mathrm{Pb}$-induced oxidative stress in carps. However, the underlying role of antioxidative activity of this strain against $\mathrm{Pb}$-induced oxidative stress and dysfunction of the gut barrier need to be investigated further. In addition, co-treatment with $\mathrm{Pb}$ and L. reuteri P16 reversed the expressions of pro-inflammatory cytokines (TNF- $\alpha$ and IL-1 $\beta$ ), which are associated with the NF- $\kappa B$ signaling pathway and subsequent decreases in reactive oxygen species production and prevents $\mathrm{Pb}$-induced cellular apoptosis. However, comprehensive $\mathrm{Pb}$ tolerance mechanisms in LAB strains have not been investigated. Therefore, $\mathrm{Pb}$ stress response network in LAB strains are yet to be elucidated. Furthermore, key proteins and pathways involved in $\mathrm{Pb}$ tolerance of lactobacilli strains are unknown. Hence, isobaric tags for relative and absolute quantification (iTRAQ)-based comparative and functional proteomic approaches could be utilized to explore $\mathrm{Pb}$-tolerance related to key proteins and pathways in L. reuteri strains. Moreover, at this early stage of research, we do not know how probiotics repair the metabolic damages occurring in fish exposed to heavy metals; therefore, efforts should be made in the future to incorporate multiple targets (genes, proteins, and metabolites) for exploring heavy metal defense mechanisms of probiotics in hosts.
Notably, treatment with $L$. reuteri P16 alone did not exert any adverse effects on growth performance, hematological and blood biochemical parameters, intestinal enzymatic activities, and intestinal microbiota. In addition, growth rate and feed utilization was greater in the group fed with only L. reuteri P16. This finding is in agreement with that of several earlier reports, which demonstrated that probiotics could boost the growth performance of fish. Furthermore, this strain exhibited higher $\mathrm{Pb}$-removing antioxidant potential in vitro (28). Results of the present study suggest that $L$. reuteri P16 supplementation is safe for the carp species studied.

\section{CONCLUSION}

Lead has deleterious effect on physiological and immune functions in fish. Exposure of fish to sublethal concentrations resulted in significant $\mathrm{Pb}$ accumulation in specific tissues, whereas L. reuteri P16 supplementation strongly reduced this. This strain significantly increased the feed utilization, growth performance, and survival of $\mathrm{Pb}$-exposed fish. L. reuteri P16 supplementations recovered $\mathrm{Pb}$ toxicity related biochemical parameters, alleviated oxidative stress, and re-established gut microbial population and intestinal enzymatic activities. 
Furthermore, L. reuteri P16 supplementation was effective in reducing the $\mathrm{Pb}$-exposure-induced expression of heat shock proteins. Overall, L. reuteri P16 supplementation showed considerable effectiveness in attenuating the changes caused by $\mathrm{Pb}$-induced toxicity. Furthermore, administration of $L$. reuteri P16 by itself did not exert any adverse effects on fish health, suggesting that the dietary supplementation of this strain is sage. Results of the study indicate that $L$. reuteri $\mathrm{P} 16$ can cope with heavy metal stress owing to induction of cellular defense and repair system, but the underlying mechanisms of $\mathrm{Pb}$ tolerance of this strain yet to be explored. Therefore, these results suggest that $L$. reuteri P16 has potency as a novel dietary supplement to prevent safety problems induced by lead pollution in carp aquaculture. Therefore, Lactobacillus strains with both good $\mathrm{Pb}$-binding and antioxidative capacities, such as L. reuteri $\mathrm{P} 16$, can be considered for utilization as dietary supplement for the prevention of $\mathrm{Pb}$ contamination aquaculture.

\section{AUTHOR CONTRIBUTIONS}

SG, VS, and SP designed the work. SG contributed significantly in lab works. SY helped him in conducting the experiments.

\section{REFERENCES}

1. Ashraf W. Accumulation of heavy metals in kidney and heart tissues of Epinephelus microdon fish from the Arabian Gulf. Environ Monit Assess (2005) 101:311-6. doi:10.1007/s10661-005-0298-4

2. Kirillova AV, Danilushkina AA, Irisov DS, Bruslik NL, Fakhrullin RF, Zakharov YA, et al. Assessment of resistance and bioremediation ability of Lactobacillus strains to lead and cadmium. Int J Microbiol (2017) 2017:7. doi:10.1155/2017/9869145

3. Squadrone S, Prearo M, Brizio P, Gavinelli S, Pellegrino M, Scanzio T, et al. Heavy metals distribution in muscle, liver, kidney and gill of European catfish (Silurus glanis) from Italian Rivers. Chemosphere (2013) 90:358-65. doi:10.1016/j.chemosphere.2012.07.028

4. Kim J-H, Kang J-C. Toxic effects on bioaccumulation and hematological parameters of juvenile rockfish Sebastes schlegelii exposed to dietary lead $(\mathrm{Pb})$ and ascorbic acid. Chemosphere (2017) 176:131-40. doi:10.1016/j.chemosphere. 2017.02.097

5. Jarüp L. Hazards of heavy metal contamination. Br Med Bull (2003) 68: 167-82. doi:10.1093/bmb/ldg032

6. Ramsdorf WA, Ferraro MV, Oliveira-Ribeiro CA, Costa JR, Cestari MM. Genotoxic evaluation of different doses of inorganic lead ( $\mathrm{Pb}(\mathrm{II})$ ) in Hoplias malabaricus. Environ Monit Assess (2009) 158:77-85. doi:10.1007/s10661008-0566-1

7. Alsop D, Ng TY-T, Chowdhury MJ, Wood CM. Interactions of waterborne and dietborne $\mathrm{Pb}$ in rainbow trout, Oncorhynchus mykiss: bioaccumulation, physiological responses, and chronic toxicity. Aquat Toxicol (2016) 177: 343-54. doi:10.1016/j.aquatox.2016.06.007

8. Paul N, Chakraborty S, Sengupta M. Lead toxicity on non-specific immune mechanisms of freshwater fish Channa punctatus. Aquat Toxicol (2014) 152:105-12. doi:10.1016/j.aquatox.2014.03.017

9. Gu Y-G, Huang H-H, Lin Q. Concentrations and human health implications of heavy metals in wild aquatic organisms captured from the core area of Daya Bay's Fishery Resource Reserve, South China Sea. Environ Toxicol Pharmacol (2016) 45:90-4. doi:10.1016/j.etap.2016.05.022

10. Zhai Q, Narbad A, Chen W. Dietary strategies for the treatment of cadmium and lead toxicity. Nutrients (2015) 7:552-71. doi:10.3390/nu7010552

11. Nayak SK. Role of gastrointestinal microbiota in fish. Aquacult Res (2010) 41:1553-73. doi:10.1111/j.1365-2109.2010.02546.x
SGK SWK, JK, and SH helped in sample collection and immunological studies. SG wrote the manuscript. All authors reviewed and contributed significantly to improve the manuscript. JJ contributed to study the immune gene expression analysis. JJ, SY, and HK contributed to statistical analysis of the data.

\section{ACKNOWLEDGMENTS}

This research was supported by the "Korea Research Fellowship Program" of the National Research Foundation of Korea (NRF), Ministry of Science and ICT (KRF: 2016H1D3A1909005), NRF research grant (NRF-2017R1C1B2004616), and Cooperative Research Program for Agriculture Science and Technology Development (Supportive managing project of Center for Companion Animals Research) by Rural Development Administration (PJ0138772018).

\section{SUPPLEMENTARY MATERIAL}

The Supplementary Material for this article can be found online at https://www.frontiersin.org/articles/10.3389/fimmu.2018.01824/ full\#supplementary-material.

12. Gómez GD, Balcázar JL. A review on the interactions between gut microbiota and innate immunity of fish. FEMS Immunol Med Microbiol (2008) 52:145-54. doi:10.1111/j.1574-695X.2007.00343.x

13. Yu L, Zhai Q, Zhu J, Zhang C, Li T, Liu X, et al. Dietary Lactobacillus plantarum supplementation enhanced growth performance and alleviates aluminum toxicity in tilapia. Ecotoxicol Environ Safety (2017) 143:307-14. doi:10.1016/j. ecoenv.2017.05.023

14. Zhai Q, Yu L, Li T, Zhu J, Zhang C, Zhao J, et al. Effect of dietary probiotic supplementation on intestinal microbiota and physiological conditions of Nile tilapia (Oreochromis niloticus) under waterborne cadmium exposure. Antonie Van Leeuwenhoek (2017) 110:501-13. doi:10.1007/s10482-0160819-x

15. Bhakta JN, Ohnishi K, Munekage Y, Iwasaki K, Wei MQ. Characterization of lactic acid bacteria-based probiotics as potential heavy metal sorbents. J Appl Microbiol (2012) 112:1193-206. doi:10.1111/j.1365-2672. 2012.05284.x

16. Majlesi M, Shekarforoush SS, Reza Ghaisari HA, Nazifi S, Sajedianfard J, Eskandari MH. Effect of probiotic Bacillus coagulans and Lactobacillus plantarum on alleviation of mercury toxicity in rat. Probiotics Antimicrobial Prot (2017) 9:300-9. doi:10.1007/s12602-016-9250-x

17. Yi Y-J, Lim J-M, Gu S, Lee W-K, Oh E, Lee S-M, et al. Potential use of lactic acid bacteria Leuconostoc mesenteroides as a probiotic for the removal of $\mathrm{Pb}$ (II) toxicity. J Microbiol (2017) 55:296-303. doi:10.1007/s12275-017-6642-x

18. Zhai Q, Wang H, Tian F, Zhao J, Zhang H, Chen W. Dietary Lactobacillus plantarum supplementation decreases tissue lead accumulation and alleviates lead toxicity in Nile tilapia (Oreochromis niloticus). Aquaculture Res (2017) 48:5094-103. doi:10.1111/are.13326

19. Mohapatra S, Chakraborty T, Prusty AK, Pani Prasad K, Mohanta KN. Beneficial effects of dietary probiotics mixture on hemato-immunology and cell apoptosis of Labeo rohita fingerlings reared at higher water temperatures. PLoS One (2014) 9:e100929. doi:10.1371/journal.pone.0100929

20. Nayak SK. Probiotics and immunity: a fish perspective. Fish Shellfish Immunol (2010) 29:2-14. doi:10.1016/j.fsi.2010.02.017

21. Newaj-Fyzul A, Al-Harbi AH, Austin B. Developments in the use of probiotics for disease control in aquaculture. Aquaculture (2014) 431:1-11. doi:10.1016/j.aquaculture.2013.08.026

22. Ringø E, Gatesoupe F-J. Lactic acid bacteria in fish: a review. Aquacult (1998) 160(3):177-203. doi:10.1016/S0044-8486(97)00299-8 
23. Giri SS, Sukumaran V, Sen SS, Vinumonia J, Banu BN, Jena PK. Antagonistic activity of cellular components of probiotic bacteria, isolated from the gut of Labeo rohita, against Aeromonas hydrophila. Probiotics Antimicrob Proteins (2011) 3:214-22. doi:10.1007/s12602-011-9078-3

24. Giri SS, Sukumaran V, Oviya M. Potential probiotic bacteria L. plantarum VSG3 improves the growth, immunity and disease resistance of tropical freshwater fish, Labeo rohita. Fish Shellfish Immunol (2013) 34:660-6. doi:10.1016/j.fsi.2012.12.008

25. Chi C, Jiang B, Yu X-B, Liu T-Q, Xia L, Wang G-X. Effects of three strains of intestinal autochthonous bacteria and their extracellular products on the immune response and disease resistance of common carp, Cyprinus carpio. Fish Shellfish Immunol (2014) 36:9-18. doi:10.1016/j.fsi.2013.10.003

26. Coelho LM, Rezende HC, Coelho LM, de Sousa PAR, Melo DFO, Coelho NMM. Bioremediation of polluted waters using microorganisms. In: Naofumi S, editor. Advances in Bioremediation of Wastewater and Polluted Soil. Rijeka: IntechOpen (2015).

27. Zhai Q, Yin R, Yu L, Wang G, Tian F, Yu R, et al. Screening of lactic acid bacteria with potential protective effects against cadmium toxicity. Food Control (2015) 54:23-30. doi:10.1016/j.foodcont.2015.01.037

28. Giri SS, Yun S, Jun JW, Kim HJ, Kim SG, Kang JW, et al. Characterisation of lactic acid bacteria isolated from the gut of Cyprinus carpio that may be effective against lead toxicity. Probiotics Antimicrobial Proteins (2017). doi:10.1007/s12602-017-9367-6

29. Sukumaran V, Park SC, Giri SS. Role of dietary ginger Zingiber officinale in improving growth performances and immune functions of Labeo rohita fingerlings. Fish Shellfish Immunol (2016) 57:362-70. doi:10.1016/j.fsi.2016.08.056

30. Drape HH, Squires EJ, Mahmoodi H, Wu J, Agarwal S, Hadley M. A comparative evaluation of thiobarbituric acid methods for the determination of malondialdehyde in biological materials. Free Radic Biol Med (1993) 15:353-63. doi:10.1016/0891-5849(93)90035-S

31. Dotta G, Alves de Andrade JI, Gonçalves ELT, Brum A, Mattos JJ, Maraschin M, et al. Leukocyte phagocytosis and lysozyme activity in Nile tilapia fed supplemented diet with natural extracts of propolis and Aloe barbadensis. Fish Shellfish Immunol (2014) 39:280-4. doi:10.1016/j.fsi.2014.05.020

32. Pavasovic A, Richardson NA, Mather PB, Anderson AJ. Influence of insoluble dietary cellulose on digestive enzyme activity, feed digestibility and survival in the red claw crayfish, Cherax quadricarinatus (von Martens). Aquacult Res (2006) 37:25-32. doi:10.1111/j.1365-2109.2005.01389.x

33. Hoseinifar SH, Mirvaghefi A, Mojazi Amiri B, Rostami HK, Merrifield DL. The effects of oligofructose on growth performance, survival and autochthonous intestinal microbiota of beluga (Huso huso) juveniles. Aquaculture Nutr (2011) 17:498-504. doi:10.1111/j.1365-2095.2010.00828.x

34. Livak KJ, Schmittgen TD. Analysis of relative gene expression data using realtime quantitative PCR and the $2^{-\Delta \Delta \mathrm{CT}}$ method. Methods (2001) 25:402-8. doi:10.1006/meth.2001.1262

35. Hansen JA, Welsh PG, Lipton J, Suedkamp MJ. The effects of long-term cadmium exposure on the growth and survival of juvenile bull trout (Salvelinus confluentus).Aquat Toxicol(2002) 58:165-74.doi:10.1016/S0166-445X(01)00233-8

36. Giri SS, Jun JW, Sukumaran V, Park SC. Evaluation of dietary (Linn F. Muell.) as a growth and haemato-immunological modulator in Labeo rohita. Fish Shellfish Immunol (2017) 68:310-7. doi:10.1016/j.fsi.2017.07.009

37. Gabbianelli R, Lupidi G, Villarini M, Falcioni G. DNA damage induced by copper on erythrocytes of gilthead sea bream Sparus aurata and mollusk Scapharca inaequivalvis. Arch Environ Contam Toxicol (2003) 45:350-6. doi:10.1007/s00244-003-2171-1

38. Flora G, Gupta D, Tiwari A. Toxicity of lead: a review with recent updates. Interdiscip Toxicol (2012) 5:47-58. doi:10.2478/v10102-012-0009-2

39. Wan AHL, Soler-Vila A, O’Keeffe D, Casburn P, Fitzgerald R, Johnson MP. The inclusion of Palmaria palmata macroalgae in Atlantic salmon (Salmo salar) diets: effects on growth, haematology, immunity and liver function. J Appl Phycol (2016) 28:3091-100. doi:10.1007/s10811-016-0821-8

40. Shahsavani D, Mohri M, Kanani HG. Determination of normal values of some blood serum enzymes in Acipenser stellatus Pallas. Fish Physiol Biochem (2010) 36:39-43. doi:10.1007/s10695-008-9277-3
41. Oner M, Atli G, Canli M. Changes in serum biochemical parameters of freshwater fish Oreochromis niloticus following prolonged metal (Ag, Cd, Cr, Cu, Zn) exposures. Environ Toxicol Chem (2008) 27:360-6. doi:10.1897/ 07-281R.1

42. Firat O, Cogun HY, Yuzereroglu TA, Gok G, Firat O, Kargin F, et al. A comparative study on the effects of a pesticide (cypermethrin) and two metals (copper, lead) to serum biochemistry of Nile tilapia, Oreochromis niloticus. Fish Physiol Biochem (2011) 37:657-66. doi:10.1007/s10695-011-9466-3

43. Wells RMG, Mclntyre RH, Morgan AK, Davie PS. Physiological stress responses in big gamefish after capture; observations on plasma chemistry and blood factors. Comp Biochem Physicol (1988) 84:565-71. doi:10.1016/03009629(86)90366-X

44. Freeman BA, Crapo JD. Biology of disease: free radicals and tissue injury. Lab Invest (1982) 47:412-26.

45. Ural MŞ. Chlorpyrifos-induced changes in oxidant/antioxidant status and haematological parameters of Cyprinus carpio: ameliorative effect of lycopene. Chemosphere (2013) 90(7):2059-64. doi:10.1016/j.chemosphere. 2012.12.006

46. Tkachenko H, Kurhaluk N, Grudniewska J, Andriichuk A. Tissue-specific responses of oxidative stress biomarkers and antioxidant defenses in rainbow trout Oncorhynchus mykiss during a vaccination against furunculosis. Fish Physiol Biochem (2014) 40(4):1289-300. doi:10.1007/s10695014-9924-9

47. Eiserich JP. Formation of nitric oxide-derived inflammatory oxidants by myeloperoxidase in neutrophils. Nature (1998) 391:393-7. doi:10.1038/ 34923

48. Adams DO, Hamilton TA. The cell biology of macrophage activation. Annu Rev Immunol (1984) 2:283-318. doi:10.1146/annurev.iy.02.040184.001435

49. Bahi A, Guardiola FA, Messina C, Mahdhi A, Cerezuela R, Santulli A, et al. Effects of dietary administration of fenugreek seeds, alone or in combination with probiotics, on growth performance parameters, humoral immune response and gene expression of gilthead seabream (Sparus aurata L.). Fish Shellfish Immunol (2017) 60:50-8. doi:10.1016/j.fsi.2016.11.039

50. Pérez T, Balcázar JL, Ruiz-Zarzuela I, Halaihel N, Vendrell D, de Blas I, et al. Host-microbiota interactions within the fish intestinal ecosystem. Mucosal Immunol (2010) 3:355-60. doi:10.1038/mi.2010.12

51. Canli M, Atli G. The relationships between heavy metal (Cd, Cr, Cu, Fe, $\mathrm{Pb}, \mathrm{Zn}$ ) levels and the size of six Mediterranean fish species. Environ Pollut (2013) 121:129-36. doi:10.1016/S0269-7491(02)00194-X

52. Rogers J, Richards J, Wood C. Ionoregulatory disruption as the acute toxic mechanism for lead in the rainbow trout (Oncorhynchus mykiss). Aquatic Toxicol (2003) 64:215-34. doi:10.1016/S0166-445X(03)00053-5

53. Han J, Ulevitch RJ. Limiting inflammatory responses during activation of innate immunity. Nat Immunol (2005) 6:1198-1205. doi:10.1038/ni1274

54. Denis F, Archambault D. Molecular cloning and characterization of beluga whale (Delphinapterus leucas) interleukin-1b and tumor necrosis factor-a. Can J Vet Res (2001) 65:233-40.

55. Sassi A, Darias MJ, Said K, Messaoudi I, Gisbert E. Cadmium exposure affects the expression of genes involved in skeletogenesis and stress response in gilthead sea bream larvae. Fish Physiol Biochem (2013) 39(3):649-59. doi:10.1007/ s10695-012-9727-9

Conflict of Interest Statement: The authors declare that the research was conducted in the absence of any commercial or financial relationships that could be construed as a potential conflict of interest.

Copyright (c) 2018 Giri, Yun, Jun, Kim, Kim, Kang, Kim, Han, Sukumaran and Park. This is an open-access article distributed under the terms of the Creative Commons Attribution License (CC BY). The use, distribution or reproduction in other forums is permitted, provided the original author(s) and the copyright owner(s) are credited and that the original publication in this journal is cited, in accordance with accepted academic practice. No use, distribution or reproduction is permitted which does not comply with these terms. 